began looking for alternatives that would not risk polluting the water. He adopted the renewables plan in 2017.

This pattern occurs across the country: for example, wind power is thriving in Republican-dominated states such as Kansas, Texas and Oklahoma. "The left sees climate change and renewables as inextricably intertwined," says Simon Mahan of the Southern Alliance for Clean Energy, a non-profit, non-partisan organization that promotes renewables in the southeast United States. "But Republicans see business opportunities with renewables, regardless of how they feel on climate change."

Germany's Energiewende didn't start with concern about global warming, either. In 1974 , a conservative farming community near the French border successfully blocked plans to industrialize the region. This resistance inspired other small towns to stand up against big development and come up with community-based renewables and energy efficiency as an alternative to top-down fossil fuels and nuclear energy. By the time carbon emissions entered the public consciousness in the late 1980s, the movement was already well established and calling for democratic accountability in the energy sector. And because Christian Democrat voters - the centre-right party in Germany - helped to launch the Energiewende, renewables enjoyed support across party lines.

Today, there are around 1,000 renewableenergy cooperatives in Germany, which have collectively invested more than $€ 1.8$ billion (US $\$ 2.1$ billion) in wind farms, solar panels and biogas plants. Its early start meant the Energiewende had space to grow before the big push for decarbonization. Germany's big utility companies showed little interest in renewables until recently; as of 2012, they owned only $3 \%$ of solar capacity and $10 \%$ of wind capacity in the country. Most other countries, however, started with large-scale wind farms and solar arrays, skipping community-level projects altogether.

No utility company today will fail to take renewables seriously. But they will fight renewable investments in their own territory by competitors - including consumers. It's no wonder that Ontario attracted developers from abroad; utility companies frequently use renewables to enter a competitor's territory. One of the biggest investors is Florida Power \& Light, which has built almost no renewables in Florida (the 'Sunshine State') but is a leader in other parts of North America. Likewise, France's EDF has built more wind capacity abroad than at home, as have Germany's Eon and RWE.

\section{EDUCATION AND DEMOCRACY}

However, there are a few community-led power projects in the United States. Anya Schoolman, executive director of the nonprofit Solar United Neighbors based in Washington DC, has organized 35 buying groups of residential solar homeowners, covering more than 865 solar installations in the wider Washington DC area. Whether they are Democratic, Republican or independent, "people feel that monopolies are sucking our communities dry", she says. Her projects face pushback from utility companies. "Some are trying to shut down rooftop and community solar movements before too many folks benefit from the technology. But once the word is out, there will be no way to shut it down," Schoolman says. "The main driver, I think, is education."

Education has many benefits. Through decades of community projects, the German people have amassed a wealth of knowledge about power generation. Today, German energy experts do not seek to sway decisions by claiming that the public lacks expertise. Instead, there are clear signs that informed public opinion sways the German government. In 2012, Germany's environment minister, Peter Altmaier, stopped supporting research

into carbon capture and storage (CCS), saying: "You cannot store carbon underground against the will of the population. I don't see any support for coal plants with CCS in any German state." Lack of public support for energy projects is less of a concern in other countries. Philip Johnstone, an energy-policy researcher at the University of Sussex in Brighton, UK, points out that "local opposition to fracking in the United Kingdom gets overridden at the national level".

Germany's phasing out of nuclear power is another case in point. Begun in 2002, the process was sped up under Chancellor Angela Merkel in the wake of the nuclear accident in Fukushima, Japan, in March 2011. To guide her accelerated phase-out, Merkel put together a 17-member ethics committee that included three bishops, a sociologist, a philosopher and an education expert, among others. The composition reflects Germany's current focus on a broader, more inclusive process. The ethics committee provided indirect social input that helped Merkel consider the wider societal

"Republicans see business opportunities with renewables, regardless of how they feel on climate change." concerns surrounding the energy sector alongside the technological issues.

The German strategy contrasts with the British response to the Fukushima disaster: the Weightman review. The

review was led by the Office for Nuclear Regulation, and its advisory panel consisted only of technical experts; civil society did not have a seat at the table. As a result, Johnstone notes, only technical issues were dealt with: "We weren't able to ask what society wants."

Johnstone says that citizen input in the German energy sector is fostered by the structure of its political system. "In addition to cities and the federal government in Berlin, German

\section{GERMANY'S TRANSITION TO RENEWABLES}

Germany has already added more non-hydropower renewable electricity — solar, biomass and offshore and onshore wind — than it ever got from nuclear power.

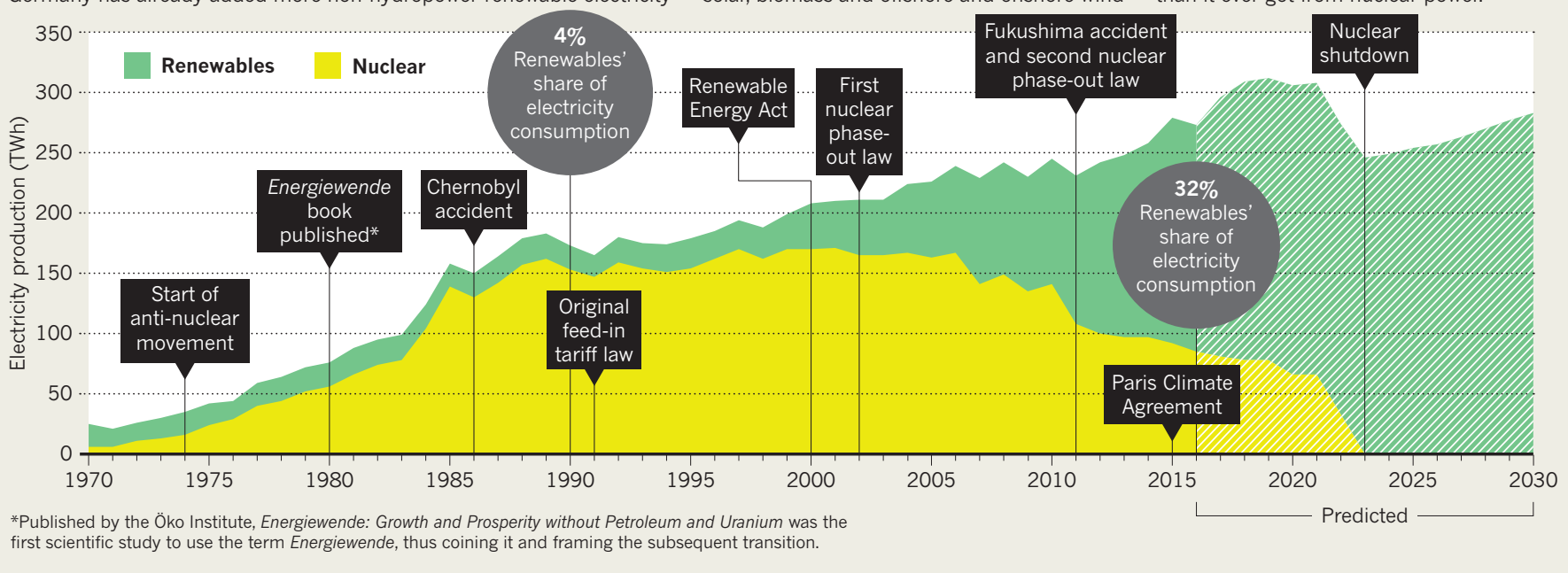




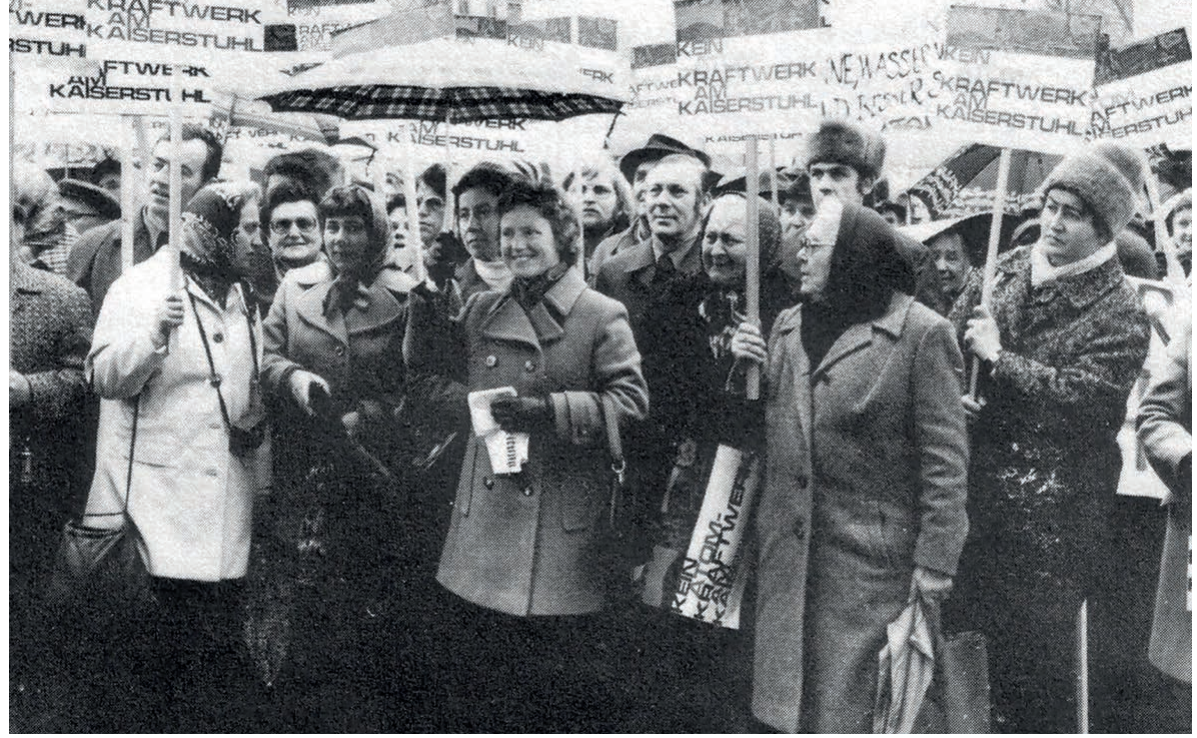

A German protest in around 1975. The signs read "no nuclear plant in Kaiserstuhl”, the region's name.

citizens have strong representation in their 16 state governments," he points out. "The Scots and Welsh have similar regional representation in their parliaments," says Johnstone, who is from Scotland, "but the English only have Westminster and city councils. There is a democracy deficit in England."

Scotland has used its regional voice to set out its own energy agenda, which has included community projects for several years; the Community and Renewable Energy Scheme has a goal of generating 500 megawatts annually from community renewables by 2020 . Regional decision-making has strengthened community renewables elsewhere in Europe as well. Paris-based energy consultant David Bourguignon says the systems of governance in Brittany, which has a unique identity in France thanks to its Celtic culture, resemble those of Germany. "Local and regional governments work hand-in-hand with citizen-led efforts in order to achieve in-depth transition," he says. France otherwise has mainly state-driven endeavours, with less grass-roots action. Likewise, the Catalonia region of Spain adopted a plan for $100 \%$ renewables this year, but the region cannot implement the plan without approval from the central government in Madrid. Renewables have thus become part of Catalonia's call for independence.

Regional and municipal decision-making leans towards renewables and efficiency. But when a national government sets the course, "national interests, such as keeping nuclear skills for national security, play a large role", Johnstone explains. He argues that regions push for local development, which often means promoting renewable-energy start-ups. "In terms of technology, Germany is thus more open to new pathways sometimes blocked in the United Kingdom - partly because the various tiers of German democracy make the country's markets more open."

\section{BOTTOM-UP INNOVATION}

Communities can be crucial innovators, but business interests can stymie innovation. Policymakers therefore have to help cash-strapped communities act, even when the private sector cannot expect a return on investments. District heat is one such example.

The heating sector consumes around $50 \%$ of total energy supply in cold countries such as Denmark and Germany, compared with about $30 \%$ for mobility and only $20 \%$ for electricity. Traditionally, each building - and sometimes each dwelling - has its own furnace to generate heat. By contrast, a district heat network can efficiently share heat energy across local buildings through connecting pipes. Such a network is effectively a shared natural monopoly, and access to it can be granted equitably to heat suppliers - no matter the size. "In the beginning, power generators used the pipes to sell their excess heat, which makes fossil-fuel consumption more efficient and power production cheaper," says Brian Vad Mathiesen, an energy systems researcher at Denmark's Aalborg University. "Gradually, renewable heat providers come on board: we make heat from excess wind power, and add more solar thermal and geothermal." Because smaller firms can compete with the big players, there are opportunities for new businesses and innovation; no big utility company can simply refuse to buy the energy.

Firms that sell fossil-fuel power might not promote district heat because they then sell less energy, which has stymied development in some countries. The Netherlands, for instance, is only now rolling out district heat networks, because it is running out of domestic natural gas. Denmark is also an oil exporter, but the Danes solved the conflict by developing consumer-owned, non-profit heat networks. People like the arrangement because they know profits are going back to the community. "Consumers may resent a corporation making profits out of a local natural monopoly like district heat lines," says Mathiesen.

Equal access to the heat network was thus crucial for renewable heat in Denmark. In the power sector, the grid served a similar role, allowing wind and solar power sellers of all sizes to be profitable. The Danish power grid is state-owned, but if regulations are stringent enough, state ownership of the grid is not necessary - Germany has four investor-owned grid networks.
Of course, community projects still install solar panels made by corporations: citizens can't do everything alone. But the reverse is also true: not much can be done without citizens. The crucial step is to find a way to get citizens involved constructively.

\section{LESSONS FOR THE FUTURE}

Bill Irwin, a policy researcher at Huron University College in London, Canada, argues that cultural attitudes affect innovation. Ontario suffers from short-term thinking and complacency, he says, whereas Germany plans for the longer term. "The German tenure with going green is in fact 35-40 years in the making," he says (see 'Germany's transition to renewables'). Energiewende is a generational project that requires time to gestate. Irwin is hopeful that the current popular backlash against wind power in Ontario is a "necessary step already taken by Germany" in an evolution towards community renewable energy.

Granted, no one wants their project blocked by nay-saying locals, but at least protesters are engaged. For their protest to be productive, people who say no to a project should be required to say what they want instead. The Germans said no to nuclear, and experts demanded to know the public's preference. The answer was renewables and efficiency.

Nine years after its Green Energy Act, Ontario has its first success stories, and they sound similar to those in Germany and Denmark. Oxford County, an hour west of Toronto, has a plan to go $100 \%$ renewable. The county started with ten wind turbines in 2016. At first, locals were concerned about the impact of the turbines, but "now that they are up and everyone can hear how quiet they are, the debate has died down considerably", explains Miranda Fuller of Future Oxford, a local campaign group that seeks a sustainable community.

Fuller outlines the other community benefits of Oxford County's scheme. "Homeowners along the edge of the wind farm were won over by the argument that farmland would be protected," she says. Farmers were worried about the sprawling town of Woodstock encroaching on their land; now, the wind farm will protect their land for at least 20 years (the service life of the turbines). The county has also built a biogas unit, fired with locally sourced bioenergy and waste, to provide new revenue streams and warm local homes through district heat lines. The impetus for this transition to renewables was that it promised improvements to the community: local jobs and citizen input in infrastructure planning. The side effect was climate protection. As Anya Schoolman would say, once word gets out, people engage.

Craig Morris is a senior fellow at the Institute for Advanced Sustainability Studies in Potsdam, Germany. Arne Jungjohann is an independent analyst in Stuttgart, Germany. They are the authors of Energy Democracy. 